\title{
TRANSLATION STRATEGIES FOR TRANSLATING A NEWS ARTICLE
}

\author{
Esti Junining, Vidi Aulia Mahendra Cahya Kusuma
}

\author{
esti@ub.ac.id \\ Universitas Brawijaya \\ Malang, Jawa Timur, Indonesia
}

\begin{abstract}
There are various kinds of translation strategies proposed by the experts of translation. This study aims to find out the translation strategies used by the English Education students from Faculty of Cultural Studies (FCS) of Universitas Brawijaya (UB) in translating a news article. The translation strategies used by the students are categorized based on the Baker's taxonomy. The result shows that the students employ all of the eight translation strategies from Baker's taxonomy in translating the news article. The three most used translation strategies are translation by using a more general word (95\%), paraphrasing using related words (75\%), cultural submission and omission (73\%). On the contrary, the least used translation strategy is translation by illustration (31\%). From the result of the study, it is suggested that researchers interested in translation can conduct more research about the students' translation in a deeper and more specific analysis.
\end{abstract}

Keywords: Translation Strategies, English Study Program Students, News Article

\section{INTRODUCTION}

In this digital era, news has been wellknown as essential aspects in the daily life. It seemed that these days, there is no boundaries nor limitation in spreading any kind of news. However, the readers cannot understand all of the news since some readers might be unfamiliar with the language used. Therefore the language used in writing the news needs to be changed to make it understandable by the readers in broader community. Translation plays an important role in achieving this goal.

Translation can be described as an activity of rendering a meaning of a text from one language to another. According to Nida and Taber (1982, p. 12) the main goals of translation is to reproduce the sourcelanguage message into the receptor language closest natural equivalence in the terms of meaning and style. It means that the main objective of translation is the "closest equivalence" in meaning and structure. However, finding the closest equivalence is not that simple.

In Newmark (1988, p.4) the dynamics of translation is illustrated below.

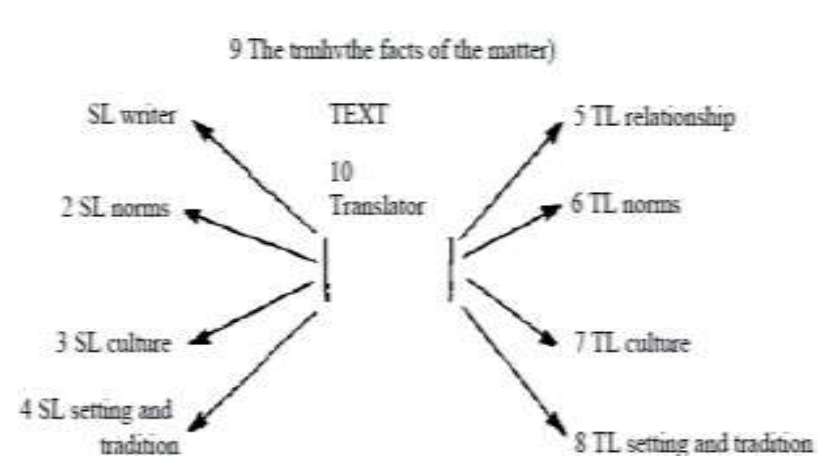

Figure 1.1 Newmark's Dynamics of Translation

Figure 1.1 illustrates the dynamics of translation. The figure shows that the center of translation is the translator. The translator should understand or, at least, know some concepts both from the SL (source-language) and the TL target-language. It is needed to make it easier for the translator to deliver every concept intended by the author of the source-language texts to the target-language. Moreover, according to Newmark (1982), a translator requires a knowledge of literary and non-literary textual criticism to assess the quality of a text before decides how to interpret 
and translate it. From the statement, it can be assumed that the translator's knowledge and the ability will greatly affect the translation process and directly affect the quality of translation product they made.

To prepare highly qualified future translators, the English Education Study Program of the Faculty of Cultural Studies from Universitas Brawijaya has prepared several translation courses. These courses are focusing on language translation from Indonesia to English and vice versa. One of the translation courses is called translation practice, it is offered for the third year English education students.

The main goals of translation practice course are to train the students to make them able to translate common texts and semiscientific texts which come from many source including magazine and news. The students of translation practice course are taught kind of issues regarding to translation studies. The learning material includes the debates of translation studies, translation training and translation quality assessment (Pedoman Pendidikan FIB-UB 2018/2019).

In the teaching and learning process, the students are introduced to some translation problems and various kind of translation method, translation procedure and strategies in dealing with the problems. They are all also given a module. The module contains materials and worksheet made by the translation lecturer. The worksheet consists of various kinds of texts including a news article, a part of research paper and some other either in Bahasa Indonesia or English. Their task is to translate the text from Bahasa Indonesia to English and vice versa as part of their translation training.

In observing the translation product made by the translation practice students, it was found that although the students are taught in the same way and asked to translate identically the same texts, their translation products can be either slightly or even greatly different. It can be seen in most of translation product they made including their translation product on a news article.

The factor which affects the students' translation product deduced coming from the individual factor (cognitive and affective). Adi (2016) stated that the hidden elements of classroom including cognitive, affective, social, psychology and culture can affect the students' teaching and learning process. It can be assumed that different way of thinking and different consideration might have motivated the students in choosing different way in translating a text.

There are some studies regarding the translation strategies. Stepanova (2016) conducted a study to identify the translation methods and strategies chosen by a group of professional translators and practicing lawyers to resolve problems in translating legal terminology. The result of the study found that different various kinds of translation strategies and methods are used in translating the legal terminology. Another study conducted by Rus and Harpa (2018). The study is a comparative study involving some students from "Petru Maior" University intended to highlight types of approach to translation practice based on the type of text and the translator's professional formation. While in Indonesia, there is a study conducted by Pujiastuti (2014) to describe the strategies used by accounting study program students of Bengkulu University in translating their abstracts from Bahasa Indonesia into English.

From the three studies mentioned above, this study focuses on translation strategy used by English Education Study Program students in translating a news article. This study is intended to find out the translation strategies used by the English Education Students of the Faculty of Cultural Studies from Universitas Brawijaya. They take the translation practice courses, in translating a news article.

This study aims to find out what the translation practice students use translation strategies in translating a news article. Theoreticaly, this study could be a reference for the future researcher to conduct a study related to translation. This study also expected to become one of the source of knowledge in translation field, in which it can provide an information for the reader regarding translation strategy.

Practically, this study's findings will rebound to the benefit of society, especially in the field of translation. With this study, people will know that translators might translate a news article differently. It happens because the translation strategies they applied are different when dealing with translation problems. Thus, 
people cannot judge that all of the translators would have identical translation products.

This study is conducted at Universitas Brawijaya (UB). The subjects of this study are the English Education Students of the Faculty of Cultural Studies from UB who take the translation practice course in the academic year 2018-2019. The news articles mentioned by the researcher are a news article which exists in the translation practice students' worksheet which is also counted as the students' task.

The translation strategies mentioned is the one which called as Baker's taxonomy. Baker's taxonomy is a set of translation strategies from proposed by Baker (2011). This set of translation strategies is chosen because it is a part of the translation practice students' learning materials. Moreover, according to Owji (2013), Baker's taxonomy includes the most applicable set of strategies because it shows the strategies used by professional translators.

Nowadays, translation plays an important role in spreading information. One of the examples can be seen on written information such as news article. The language used in writing the news article is changed to make it understandable by the target readers. In Newmark (1988) the dynamics of translation illustrate that the center of translation is the translator. The translator should be able to understand several aspects, both from source-language and the targetlanguage to deliver the message intended by the author on its source-language text.

In Faculty of Cultural Studies (FCS) of Universitas Brawijaya (UB), several translation courses, including translation practice, are offered to prepare a highly qualified future translation. Even though the translation practice students learn the same thing and asked to translate the same texts, the translation product they made is different including their translation product on a news article. The differences they made in their translation product were caused by different ways or strategies of translating the texts. Some previous studies regarding translation strategies done by Stepanova (2016), Rus and Harpa (2018), and Pujiastuti (2014) have encouraged the researcher to conduct this study.
Translating legal document has different strategies to employ. It is in line with Stepanova (2017) who wrote about the complexities of translating legal documents. In his research he found that concerning the scope of knowledge and skills needed to feel confident in legal translation, the translator should be able to operate internationally and/ or translate legal texts should be recognized.

Different from Stepanova (2016), translation news articles need considering several factors such as originality, translation tools, the translation process, and the strategies they use to translate (Suryawinata and Hariyanto, 2003). Translating news article needs to consider appropriate strategies to employ.

From the preliminary study, the translation strategies used by the English Study Program students in translating the news articles are very diverse. The first strategy used is translation by more general word. In this strategy, there are 82 out of 86 general words that are employed. Translation by more general word is the transformation of text from one language to another at a time with or without conveying the meaning of the original whole. By using this strategy, the students directly translate words in Indonesian language. Usually, literal translation commonly used to translate. Based on Newmark (1988), this method is mostly used as a first step to translate article or many things. Yet, not many students understand on how to translate a word in more general way.

Most of the students use omission. Omission is described as the act of omitting or leaving something out a piece of information or a thing left out. Omission is often applied when the translator has no ideas on translating the appropriate words. Most of the students prefer to omit some untranslatable words due to this problem. However, employing omission in translating a text cannot be too much to employ.

Another strategy used is borrowing. Borrowing is a common translation technique by using a word or phrase adopted from one language into another. It means that the translator makes a conscious choice to use the same word in the target text as it is found in the source text. Most of the students prefer to use borrowing to translate news articles, however, the choice of the borrowing is often 
inappropriate. The result of the preliminary analysis supports this study as one of the evaluations of the student's work.

\section{LITERATURE REVIEW}

From the early translation study up till now, many translation experts have proposed their theories in translation. One of the theories in translation well known by translation experts around the world is a theory proposed by Eugene A. Nida. He is a linguist famous by his experience as a Bible-translator and dominating the literature of translation study. Nida has also proposed his definition of translation which represent the perspective of his theory. To find the deeper meaning of translation, theories from different disciplines are discussed and analyzed in Nida (2001). The conclusion leads to the definition of translation which related to the "closest natural equivalent".

Some years later, Ran (2009) conducted a study to analyze the Nida's definition of translation from philosophical interpretation and found that the "equivalence" in Nida's definition is not completed because it does not limit the level of equivalence. Mona Baker (2011) analyzes the equivalence at word level and equivalence above word level, including grammatical equivalence, textual equivalence and pragmatic equivalence, which means that the "equivalence" is hierarchical.

\section{Non-Equivalence at Word Level}

Baker (2011) proposed that equivalence is having its hierarchy or levels. One of its levels is at the word level. It means that word level is equivalent from the source-language to the target-language. However, in translating a text, a translator may find a problematic word which is hard to translate since it has no exact or proper equivalence in the target language. It is called non-equivalence at word level. In Baker (2011), the problems of "nonequivalence at word level" are classified. The classifications of the problems are as follows:

\section{Culture-Specific Concepts}

Different culture may inflict an equivalence problem in translation, this problem in called culture-specific concepts. It occurred when the word from source-language express a concept which is unknown in the target culture. The concept may be concrete or even abstract and related to a religious belief, social custom or even type of food. For example, there is a concrete concept such as airing cupboard in English unknown in most other languages. In Indonesia, there is also an abstract concept like ketua $R T$ which is unknown in some languages.

\section{The Source-Language Concept is Not Lexicalized in the Target-Language}

This type of non-equivalence problem is nearly the same with the culture specific concepts. This problem happens when the source-language concept is known in the target-language but not lexicalized. The example is the word standard. It expresses a concept which is easy to understand but this word has no equivalence in Arabic.

\section{The Source-Language Word is Semantically Complex}

One of the common problem of translation is a semantically complex word. Even when the word is morphologically simple, it may express a complex set of meaning. The word itself can be as simple as arruacao or even googling. Arruacao is a Brazillian word which means 'clearing the ground under coffee trees to prepare for the harvest'. Googling is an activity of searching any kind of information in the internet by using Google.com as the search engine.

\section{The Source and Target Languages Make Different Distinctions in Meaning}

Translator may also deal with a case where the target-language make a distinction in meaning than the source-language. Another language may not regard an important distinction in meaning like one language do. For example, in Indonesia, there is hujanhujanan and kehujanan. indonesia make a distinction between going out in the rain by knowing that it is raining (hujan-hujanan) and going out in the rain without knowing that it is raining (kehujanan). This distinction may even not exist in another language such in English.

\section{The Target Language Lacks a Superordinate}

This is a translation problem where the target-language may have a specific words (hyponyms) but no general word (superordinate) to represent the meaning. For example, the word facilities (any equipment 
provided for a particular purpose) has no ready equivalent in Russian. However, there are several specific words which express the types of facilities in Russian just like neobkhodimye pomeshcheniia (essential accommodation), sredstva peredvizheniya (means of transport) and neobkhodimoe oborudovanie (essential equipment).

\section{The Target Language Lacks a Specific Term (Hyponym)}

This problem is one of the common problem in translation. It is a problem where the target-language may have a general word (superordinate) but lack of specific word (hyponyms). There are many example of this problem since it is very common. In English, there are several hyponyms under the word house which have no equivalents in many languages, just like bungalow, cottage, hut, mansion, lodge, croft, manor, villa and hall. Under the word jump, there is also some hyponyms such as leap, vault, spring, bounce and dive.

\section{Differences in Physical or Interpersonal Perspective}

This problem related to a condition where one language regards physical or interpersonal perspective more important than in another language. The physical perspective deals with the position of things or people concerning another or to a place. It expressed in pairs of words such as come/go, take/bring, arrive/depart and many other. The interpersonal perspective deals with the relationship between participants in a condition. For example, depending on who gives to whom, Japanese has six equivalents for the word give which are yaru, ageru, morau, kureru, itadaku and kudasaru.

\section{Differences in Expressive Meaning}

This problem deals with a condition where a word in the target language may have the same propositional meaning with the word in the source-language, but with a different expressive meaning. The difference might be considerable but important enough to pose a problem in given context. When the targetlanguage is more neutral compare to the source-language, the translator might add the expressive meaning if necessary. For example, it is possible to render the word batter (as in child battering) by the more neutral Japanese word tataku (to beat), plus an equivalent modifier such as 'savagely' or 'ruthlessly'.

\section{Differences in Form}

In translation, there is a condition where there is no equivalent in the target-language for a particular form of word in the sourcelanguage. Some prefixes and suffixes which convey propositional and other types of meaning in English often have no equivalents in other language. For example, Arabic has no equivalent for some suffixes like -ish (boyish, hellish, greenish) and -able (drinkable, readable, retrievable). Usually, this problem is solved using paraphrase depends on the meaning they convey just like drinkable which means 'suitable for dinking'.

\section{Differences in Frequency and Purpose of Using Specific Forms}

It is a condition where there is a difference in the frequency and the purposed of particular form between the source-language and the target-language. English uses the continuous -ing form for binding clauses much more frequently than other languages which have equivalents. For example, when German and the Scandinavian languages rendering every -ing form in an English source text with an equivalent -ing form in a German, Danish or Swedish target text, it would result in unnatural style.

\section{The Use of Loan Words in the Source Text}

It is a condition where the source text contains a loan word from another language or the target language. The word is used because they can add sophistication to the text or the subject matter. Japanese tends to use loan words widely just for effect because they sound beautiful and look elegant. However, this effect is often lost in translation especially if the loan word is originally from the target-language because the stylistic effect of the word would have to be sacrificed in the translation process.

Translation is the process to transfer or to put up something written or spoken in a different form from the Source Language (SL) into the Target Language (TL) to communicate the message to the target language readers is stated by Zoraya et al (2017). Based on that statement, translation deals with the 
complexity of language, which means many problems, arise when people want to translate an idea or information. The general problem if people want to translate is the need to choose appropriate terms with more than one (ambiguous) meaning. Also, the ability to find the correct definition of expression from the Source Language (SL) into the Target Languge (TL) if it does not have the sense of the certain word from the source language.

In general, translation modified a text from one language to another without changing the meaning or concept that existed in the language of origin. According to Newmark (1988), translation is the way the author interpreted the text rendered the context of a text in another language. Instead, in Hartono (2012), Sperber and Wilson claimed that translation replaced a text in one language with second language representation of an identical text. This definition means that the translator must create the target text as representing the corresponding source text by translating a text into another language.

Translation is not just changing the language into another language. According to Baker (1992), a good translator could not start translating until she or he had read the text at least once and had in the text a ' gist ' of the message as a whole. Once the source text was known, the job of the translator was to create a translation service that could be recognized in its language and culture as a text. The target version's words, collocation, and grammatical pattern should meet the target language requirements. Collocation patterns and grammatical structures could then only improve the ability to interpret information from individual sentences. Lastly, we should ensure that these sentences and paragraphs are readable and clear.

Equivalence was a state of being equal. According to Newmark (1988), the main purpose of any translation should have an equal effect, i.e. delivering the same or as close to the readership of the translation as possible. It meant that the general purpose of translating a target text was to reach the source text's equivalence. Therefore, the meaning of translation equivalence was a state of the source text and the target text is being equal in meaning. Still, the language's differences, meaning, and message from the source text were transferred naturally to the target text. So, it looks like it is not translated.

Baker (2011) suggested that equivalence has its hierarchy or levels. One of its levels is at the word level. It means that word level is equivalent from the source-language to the target-language. However, in translating a text, a translator may find a problematic word that is hard to translate since it has no exact or proper equivalence in the target language. It is called as non- equivalence at the word level.

\section{Translation Strategies}

From the problems of non-equivalence at the word level, Baker (2011) highlighted several approaches that professional translators have used to address translation. Owji (2013) called this set of translation technique the taxonomy of Baker. Baker's translation strategy taxonomy provides the most appropriate set of strategies, because it displays the techniques used by experienced translators. Here, this definition indicates the applicability of these strategies. The translation strategies in it are as follows:

\section{Translation by a More General Word (Superordinate)}

In translation, it is one of the most used strategies and works well in most languages. Using this strategy, the translator simply translates the source-language specific word into a general word in the target language. For example, leap, vault, spring, bounce which can be represented by the general word jump can be translated into lompat in Bahasa Indonesia.

\section{Translation by a Neutral/ Less Expressive Word}

In translation, a translator can also decrease the expressive meaning of a word if it is necessary. Translation by a less expressive word is a way to solve the non-equivalence problem by decreasing the expressive meaning of the word or making it sound more neutral/common. In English, the word skyscraper's expressive meaning can be downgraded by using a word like a tall building.

\section{Translation by Cultural Substitution}

Translation by cultural substitution allows the translator to replace the culture- 
specific item or expression with the targetlanguage item, which could impact the reader. The main advantage of using this strategy is that it provides the reader with a concept that can be identified as something familiar. Using this strategy, the translator's decision will largely depend on the authority given, the purpose of the translation and the translator's judgment.

\section{Translation Using a Loan Word plus Explanation}

In translation, it is possible to translate a word just by adding the explanation after the word. Translation using a loan word is a translation technique in which the translator may leave the word just as it is in the source language texts but accompanied by the target language description. When explained, it is possible to use the loan word alone. There is no need to re-explain the word because its length of description can distract the reader. For example, katana (a sword originated from japan used by a samurai).

\section{Translation by Paraphrase Using a Related Word}

The translator applies translation by paraphrase using a related word by choosing a different form to lexicalize the concept expressed by the source-language. This strategy is simply replacing the sourcelanguage word with the synonyms in the target language. For example, terraced can be translated to the target language to an item that stands for "created in a terrace". It also works for the word creamy which can be translated as "that resembles cream". Both of them are still related to each other.

\section{Translation by Paraphrase Using Unrelated Word}

Translation by paraphrase using unrelated word is used when the source item is not lexicalized at all in the target-language. This strategy is bit awkward to use since one slot of a word from the source-language will be filled by explanation consisting of several words in the target language. For example, (....... the areas most accessible to and disturbed by Man) translated into (....... the places where human beings enter most easily and interfere most).

\section{Translation by Omission}

Translation by omission is a translation strategy where the translator can omit particular item or expression which is not vital enough in delivering the meaning to the target language. When this strategy applied, the translation product will likely become very smooth. However, it might be less expressive. Moreover, there is a possibility that there will be a loss of meaning in the translation process. Therefore, this strategy is advised to be used as the last resort.

\section{Translation by Illustration}

Translation by illustration helps the translator to solve the non- equivalence problem regarding a physical entity. The word is simply replaced with an illustration in the form of the picture. For example, the word tagged as in tagged teabag is not easy to translate without using a long explanation. Here, an illustration of tagged teabag can be used instead of paraphrase.

Similar studies about strategies in teaching speaking firstly have been conducted by Junining (2014) entitled "Translation Strategies Adopted by English Department Students in Coping with Non Equivalence Problems". This study employs three genres of the text namely informational. literary and news. The next is by Stepanova (2017) who wrote about "Translation Strategies of Legal Texts: Experimental Approach". The study is aimed to identify translation methods and strategies chosen by some professional translators and practicing lawyer in resolving problems in translating legal terminology.

Further previous study was conducted by Lovihandrie, Mujiyanto, Sutopo (2018) entitled "The translation strategy used by lingliana in translating taboo words in sylvia day's bared to you". The study investigates the strategies Indonesian translators use to translate taboo words in Silvia Day's novel entitled 'Bared to You'. The main idea of the present study is similar with the three previous studies mentioned because this study will focus on the topic regarding the translation strategy.

\section{METHOD}


This study is intended to find out the translation strategies used by the students of English Study Program taking Translation Practice course in translating a news article. The news article is the news articles existed in the translation students' worksheet retrieved from time.com. The translation strategies used were categorized based on a list of translation strategies proposed by Baker (2011) or Baker's taxonomy. There are two translation classes with around 35 students in each class. A Guttman scale questionnaire is adapted from Pujiastuti (2014) to determine the translation strategy that the students used in translating the news article. Before the questionnaires were given out to the students, the questionnaire validity was checked by using SKALO and expert validation. The data collected from the students also crosschecked with the students' translation products.

\section{FINDINGS AND DISCUSSION}

From the data obtained from the questionnaire, the translation strategies frequencies were ranked. The most used translation strategy in translating news article is translation by a more general word (95\%) and followed by translation by paraphrasing using a related word on the second place $(75 \%)$. Both translation by cultural substitution and translation by omission are on the third place (73\%). On the fourth place, there is translation by using loan word plus explanation (65\%). Translation by less expressive word is on the fifth place (58\%), followed by translation by paraphrasing using unrelated word on the sixth place (44\%) and translation by illustration on the seventh place (31\%). The data table can be seen as follows:

Table 1. Translation Strategies Used by the Students

\begin{tabular}{|c|c|c|c|c|}
\hline \multirow{11}{*}{ 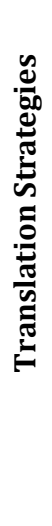 } & Aspects & Answer & $\begin{array}{l}\text { Freq. } \\
(\mathrm{F})\end{array}$ & $\begin{array}{c}\text { Percentage } \\
(\%)\end{array}$ \\
\hline & More & Yes & 52 & 94.54 \\
\hline & $\begin{array}{l}\text { general } \\
\text { word }\end{array}$ & No & 3 & 5.45 \\
\hline & \multicolumn{2}{|c|}{ Total } & 55 & 100 \\
\hline & \multirow{2}{*}{$\begin{array}{l}\text { Less } \\
\text { expressive } \\
\text { word }\end{array}$} & Yes & 32 & 58.18 \\
\hline & & No & 23 & 41.82 \\
\hline & \multicolumn{2}{|c|}{ Total } & 55 & 100 \\
\hline & \multirow{2}{*}{$\begin{array}{l}\text { Cultural } \\
\text { Substitution }\end{array}$} & Yes & 40 & 72.73 \\
\hline & & No & 15 & 27.27 \\
\hline & \multicolumn{2}{|c|}{ Total } & 55 & 100 \\
\hline & & Yes & 36 & 65.45 \\
\hline
\end{tabular}

\begin{tabular}{|c|c|c|c|}
\hline $\begin{array}{l}\text { Loan word } \\
\text { plus } \\
\text { explanation }\end{array}$ & No & 19 & 34.55 \\
\hline \multicolumn{2}{|c|}{ Total } & 55 & 100 \\
\hline \multirow{2}{*}{$\begin{array}{l}\text { Paraphrase } \\
\text { using a } \\
\text { related } \\
\text { word } \\
\end{array}$} & Yes & 41 & 74.54 \\
\hline & No & 14 & 25.45 \\
\hline \multicolumn{2}{|l|}{ Total } & 55 & 100 \\
\hline \multirow{2}{*}{$\begin{array}{l}\text { Paraphrase } \\
\text { using } \\
\text { unrelated } \\
\text { word }\end{array}$} & Yes & 24 & 43.64 \\
\hline & No & 31 & 56.36 \\
\hline \multicolumn{2}{|c|}{ Total } & 55 & 100 \\
\hline \multirow[t]{2}{*}{ Omission } & Yes & 40 & 72.73 \\
\hline & No & 15 & 27.27 \\
\hline Total & & 55 & 100 \\
\hline \multirow{2}{*}{ Illustration } & Yes & 17 & 30.9 \\
\hline & No & 38 & 69.1 \\
\hline \multicolumn{2}{|c|}{ Total } & 55 & 100 \\
\hline
\end{tabular}

\section{Translation by a More General Word (Superordinate)}

Among all of the translation strategies in Baker's taxonomy, translation by more general word is the most used translation strategy by the translation practice students in translating the news article. It is in the first place, used by 52 out of 55 or about $95 \%$ of the translation practice students. The high percentage is reasonable since many experts in translation acknowledge this translation strategy. In Baker (2011), this strategy is claimed to be one of the most common strategies and works well in translating most or even all languages. It is since it can be used to deal with many types of non-equivalence since the hierarchical structure of semantic fields is not languagespecific. In Newmark (1988), this translation strategy is labeled as translation procedure called Synonym. Newmark (1988) also stated that "A translator cannot do without synonymy; he has to compromise, to translate more important segments of the text, segments of the meaning, more accurately".

\section{Example 1}

SL : ......residents of the West Coast.....

TL : $\quad$........ penduduk pesisir barat......

From one of the students' translation product, the word "coast" which can be translated as "pantai" in Bahasa Indonesia, is translated into "pesisir". The word "pesisir" 
itself has a wider meaning and could represent the word "pantai" in Bahasa Indonesia.

\section{Example 2}

$$
\begin{array}{ll}
\text { SL : } & \text {......banyak jajan pasar } \\
& \text { disajikan pada upacara itu } \\
\text { TL : } & \text {.......there are many traditional } \\
& \text { foods served in the ceremony }
\end{array}
$$

The word "jajan pasar" actually is very specific, jajan meaning snacks are varied, yet the translation is only foods, which is very general.

\section{Translation by Paraphrase Using a Related Word}

Translation by paraphrasing using a related word is used by $74.54 \%$ of the translation practice students. This strategy used to translate a concept from SL which can be lexicalized in TL, even if the concept is lexicalized in a slightly different form. It is used to make the translation product as natural as possible.

\section{Example:}

SL: $\quad$......residents of the West Coast......

TL: $\quad$.......penduduk pantai barat.......

There is a concept in the news article which has a high possibility to be translated by using this strategy. The concept from the word "coast" is known in Bahasa Indonesia as "tempat bertemunya lautan dan daratan". That is the nearest word equivalence chosen by one of the students that could represent this concept and would sound natural in Bahasa Indonesia is "pantai". This word can also be translated as "pesisir".

\section{Translation by Cultural Substitution}

Translation by cultural substitution is used by 40 out of 55 students or about $73 \%$ of them. This strategy is used when the translator deals with a problem in translating culturespecific item or expression. This strategy allows the user to completely replace the word with the TL item which has the same impact when it is read by the readers.

\section{Example:}
SL: The eclipse's totality began around 7:41 a.m.

TL: Gerhana bulan total dimulai sekitar 7:41 pagi

There is a cultural concept regarding time in the news article, it is shown in the following phrase "around 7:41 a.m. The concept "a.m." is different from Indonesian culture, since people in Indonesia distinguish the time differently. People in Indonesia are more familiar with "pagi, siang, sore, and malam" while the concept of "a.m." or "p.m." is unknown from the Indonesian culture perception.

\section{Translation by Omission}

Translation by omission is also used by $72.73 \%$ of the students. The application of this strategy is quite easy and when it is applied, the translation product will likely become very smooth. It can be done as long as the omitted word is not vital enough in delivering the meaning.

\section{Example:}

SL: $\quad$ Much of the world looked up to the skies......

TL: $\quad$ Hampir semua orang di dunia menatap langit........

In the article, there is "looked up to the skies" which in Bahasa Indonesia, it can be easily translated as "melihat ke langit", "mengawasi langit" or "menatap langit". The word "up" can be omitted since, without translating the word "up", people should have already known that the sky is up there, as in "menatap langit". Moreover, if the translator translates it word by word as "melihat ke atas langit", it would be less natural.

Even if it sounds like a very good translation strategy, this strategy is a backword. When this translation strategy applied, the translation product made by the translator might become less expressive. Moreover, if the translator is not careful, there is also a possibility that there will be a loss of meaning in the translation process. Therefore, even the one who proposed this strategy, Mona Baker, advised that this strategy used as the last resort, when the advantages outweigh the disadvantages. 


\section{Translation Using a Loan Word plus Explanation}

The 4th rank is obtained by translation using a loan word plus explanation with $65 \%$. This translation strategy has many benefits. It is also quite common in dealing with the culture-specific concepts and modern concepts and buzzing words. The use of this strategy is also quite simple, it can be done by simply written the SL word as it is but followed by the explanation in the TL. When a loan word is already explained, there is no need to reexplain it when it shows up again in the same text because there is a possibility that its length explanation could distract the reader.

This translation strategy has the same concept with the translation procedures proposed by Newmark (1988) called, descriptive equivalent and functional equivalent. The descriptive equivalent is used to simply describing or explaining any concept from SL to TL. On the other hand, the functional equivalent is more dealing with the culturespecific concept. Functional equivalent used to deculturating a cultural word by explaining cultural word with culture-free word. Both of them are similar to his translation strategy in terms of explaining.

The translation practice students might mistake translation by illustration as this strategy because when dealing with physical entity. It is due to the lack of understanding about these two strategies. The differences between these two strategies can be seen clearly. When dealing with physical entity, translation by illustration allows the translator to replace the word being translated with a picture, while translation using loan word plus explanation allows the translator to illustrate the physical condition of the physical entity.

\section{Translation by a Neutral/Less Expressive Word}

Translation by a neutral/less expressive word is used by around $58.18 \%$ of the students. the idea of this strategy is to express the SL concept to the one level below it. Finding it unnatural or not suitable when translating the exaggerated concept, the translator can replace it with the less expressive concept as long as the meaning conveyed is still the same.

Example:
SL: $\quad$......rare celestial phenomenon that hasn't occurred since.....
TL: ......fenomena langit langka yang terjadi sejak....

In the news article, there is a word "celestial phenomenon". This word has no straight equivalent word on the same level in Bahasa Indonesia, but it can be translated as "fenomena langit". It conveys a less expressive meaning since "celestial" conveys something in space or beyond the sky. The word "sky" is one level below "celestial". However, the word "fenomena langit" feels more natural in Bahasa Indonesia and it conveys a not too different meaning with "celestial phenomenon".

This strategy shares the same risk with translation by omission. Since the word used is less expressive, the translation product made by the translator might reach the level where it is too common and unable to convey the same meaning intended by the author. That is the risk of using this strategy.

\section{Translation by Paraphrasing Using Unrelated Word}

This strategy is used by only 24 out of 55 students or about $43.64 \%$ of the students. It allows the translator to unpack the meaning of the source item using not straightly related words. This kind of strategy makes the translation product a bit awkward since the slot for one item in SL would be filled with several items in TL.

Example:

SL: The rarity of the Instagram-worthy sight meant many people worldwide woke up early to catch a glimpse of the unique lunar eclipse

TL: $\quad$ Banyak orang-orang di seluruh dunia yang bangun untuk melihat sekilas gerhana bulan ini dan mengabadikannya di Instagram

In the news article there is a word "Instagram-worthy" which could be the most complex word in this news article. Using this strategy, the word is translated to 
"mengabadikannya di Instagram" and can be translated as "layak di posting di Instgram". The word becomes a bit awkward since the translated version becomes longer.

\section{Translation by Illustration}

This strategy is used by only $30.9 \%$ of the students and it becomes the least used translation strategy in translating the news article. This strategy is helpful when the translator deals with a condition where they have to translate a physical entity lacking equivalent in the target language. Rather than giving a long explanation about the physical appearance, this translation strategy allows the translator to give an illustration or a picture to replace the word being translated. The translator should have already seen and understood the appearance of the physical entity to use this strategy. However, there is a high possibility of mistaken this translation strategy with translation by loan word plus explanation.

It happens because the fact that translation by illustration is rarely used and the students might misunderstand this strategy's application. When the translator translate a physical entity using the translation by loan words plus explanation, the translator can just write the word and give the explanation by describing the physical structure or illustrating the physical entity by using words. On the other hand, translation by illustration allows the translator to illustrate the physical entity by using a picture. From the experts' point of view, this strategy is also rarely used since in using this strategy, the translator should already see and understand the detailed appearance of the physical entity.

\section{CONCLUSION}

From the findings, it can be concluded that all of the eight translation strategies from Baker's taxonomy are used by the students in translating the news article. Most of the students use at least one of them. From all of the translation strategies in Baker's taxonomy, the three most used translation strategies are firstly, translation by using a more general word which is claimed to be the most common translation strategy used by most of the translators. This strategy is used by around $94.54 \%$ of the students. Secondly, paraphrasing using related words tend to be the second most favorite strategies (75\%). Thirdly, cultural submission (73\%) and omission $(73 \%)$ are the third most preferred strategies in translation. On the contrary, the least used translation strategy is translation by illustration that is used by only $30.9 \%$ of the students.

Some suggestions that might be beneficial for some researchers are also presented. The first recommendation is for the researchers interested in investigating translation. It is recommended for further study on strategies used by students in translating different kinds of texts such as in translating song lyrics, poems, scientific paper and others. The second is investigating students' translation in deeper analysis. It is hoped that the future researchers can conduct more research about the students' translation in a more specific analysis.

\section{REFERENCES}

Adi, S. S. 2016. Classroom Management. Malang: UB Press.

Arikunto, S. 1986. Prosedur Penelitian Suatu Pendekatan Praktek. Jakarta: Bina Aksara.

Ary, D., Jacob L.C, and Sorensen, C. 2010. An Introduction to research in Education. USA: Wadsworth.

Baker, M. 2011. In other words: A coursebook on translation 2nd Edition, London and New York: Routledge

Junining, E. 2014. Translation Strategies Adopted by English Department Students in Coping with Non-Equivalence Problems. (https://erudio.ub.ac.id/index.php/erudio/article/view/157) Vol.2 No.2 tahun 2014, pp.60-64 
Junining, E. 2018. Translation Practice Worksheet. Malang: UB

Junining, E. 2019. Strategi dan Kiat Praktis Penerjemahan. UB Press. Malang.

Morissan. 2015. Metode penelitian survei. Jakarta: Kencana

Newmark, P. 1982. Approaches to Translation, Polytechnic of Central London: Pergamon Press

Newmark, P. 1988. A Textbook of Translation. Prentice Hall

Nida, E. A. 2001. Contexts in Translating. John Benjamins

Nida,E.A. \& Taber,C.R. 1982. The Theory and Practice of Translation, Leiden: E.J.Brill

Oppenheim, A.N. 1992. Questionnaire design and attitude measurement. Great Britain: Pinter Publishers Limited.

Owji, Z. 2013. Translation Strategies: A Review and Comparison of Theories. Translation Journal (http://translationjournal.net/journal/63theory.html). Vol.17 - No. 1. January 2013. Last updated on: 07/19/2018

Pujiastuti, S. 2014. A Survey On Translation Strategies Used By Accounting Study Program Students In Translating Undergraduate Thesis Abstracts. Bengkulu: University of Bengkulu

Ran, S. 2009. Philosophical Interpretation on E. A. Nida's Definition of Translation. China

Riduwan, M.B.A. 2007. Belajar Mudah Penelitian untuk Guru-Karyawan dan Peneliti Pemula. Bandung: Alfabeta.

Rus, D. \& Harpa, E. 2018. Technical vs. general translation practices and methods: a comparative study, Elsevier B.V.

Stepanova, V. V. 2016. Translation strategies of legal texts: experimental approach, Elsevier Ltd

Suryawinata, Z. \& Hariyanto, S. 2003. Translation: Bahasan Teori dan Penuntun Praktis Menerjemahkan. Yogyakarta: Kanisius.

Tim penyusun Buku pedoman Akademik. 2015. Pedoman Pendidikan Fakultas Ilmu Budaya Universitas Brawijaya. Malang: UB

Widhiarso, W. (2011). SKALO: Program Analisis Skala Guttman. Program Komputer. Yogyakarta: Fakultas Psikologi Universitas Gadjah Mada. 